ISBN 978-81-933894-1-6

International Conference on Arts, Social Sciences, History and Interdisciplinary Studies

(ASSHIS-2017)

Kyoto (Japan) April 20-21, 2017

\title{
The Administration According to Good Governance of the Office Sheikhul Islam. Bangkok, Thailand
}

\author{
${ }^{1}$ Dr Prasert Suksaskawin, ${ }^{2}$ Dr.Tosaporn Mahamud, ${ }^{3}$ Ms Kulchalee Thupatemee \\ ${ }^{1}$ Siam technology Collage ,Bangkok Thailand \\ ${ }^{2}$ Kasembundit University, Bangkok Thailand \\ ${ }^{3}$ Eastern Asia University, Pathum Thani, Thailand
}

\begin{abstract}
Doing this research The purpose is to study the administration according to good governance of the Office Sheikhul Islam. Bangkok And to study the problems and solutions of administration according to good governance of the administration applying good governance of the Office Sheikhul Islam. Bangkok, Quantitative Research Methods The samples used in the study of 360 people, the study found that the public administration according to the good governance of the Office Sheikhul Islam. Bangkok Overall, the high level considering that each side. In all aspects The research found that

1. Social Work or service work, the first executive officers and employees are based on good governance in their work. Awareness and responsibility for their assignments. Because it is a work of public authorities and social organizations at the close of Muslims. And the trust of Muslims in Thailand.

2. The service provides equality to all parties. Without options, the importance of any individual. Or intimate personal power and prestige because everyone has equal rights.

3. Management Policy There are plans to develop clearly on Islamic Affairs, which can be implemented as appropriate and to take policy. The practice is shaped by the needs of the public.

4. Muslims should allow people in Thailand. Commenting on the management of the Bureau Sheikhul Islam. Bangkok The only people who know their problems. And has participated in working groups, which are an expression of the people doing the work. Operations Transparent accountability Get ready for inspection

5. Provide information to the public invite Muslims to attend the meeting or referendum in the development of management. Bureau of Sheikhul Islam The Muslim population was to be the mouthpiece of the evaluation.
\end{abstract}

Keyword: governance Administration

\section{Introduction}

Administration (Administration) is critical to the operation of the organization because it is a point to success. And failure The efficiency or inefficiency of the organization. The current administration is more complex in the past. But the management of the state agency is still in the adjustment. It also is familiar with the style of management is management of modular (Fragment administration) was the result of each unit and individual persons are geared to specific parts of their work. Do not focus on the coordination and integration with other entities or individuals. The administration does not effectively and efficiently as they should. This integrated management that takes into account the goals and needs of the people. Coordination between all involved will help lead to better governance (Good governance) under the participation of all sectors of unity. This will benefit the nation and the people as a whole anyway. 
Islam is managed properly managed and good governance is considered one of the articles of association, religion and Muslims must be considered for support. To learn and understand the teachings of their religion. Indeed, studies and management and administration and the accuracy used, it is essential for human life. In any society, if people lack good management. Society was without quality people and in Islam, God has given human beings learned from the cradle to the grave. Every Muslim is obliged to seek knowledge. In terms of a duty to find sustenance and loyalty to God. Muslims must be loyal to God as if he had to die tomorrow, but in the meantime, he said, they must learn the various sciences as though he had lived in this world for a long time. As a tool to bring people to success in this world and the next world is education. And that every Muslim must learn to guide lifestyle is. Quran and the Sunnah of the Prophet Muhammad Shaikh Hriiwatr.

As can be seen from the history and importance of the issues mentioned above. The research is very interesting to study the administration according to good governance of the Office Sheikhul Islam. Bangkok In order to see the good governance that is essential for the management of the organization. Whether the organization is a private or public organization. And look up its value. To study the issue and develop guidelines administered by the good governance of the administration according to good governance of the administration according to good governance of the Office Sheikhul Islam. Bangkok The results of the research to be adopted by the administration of good governance for executives. relevant person And to plan management policy in various fields. Within the organization are consistent with good governance and can be an example to other organizations, other parishes. It very good

\section{Research Objectives}

1. To study the administration applying good governance of the Office Sheikhul Islam. Bangkok

2. To study the problems and solutions of administration according to good governance of the administration according to good governance of the Office Sheikhul Islam. Bangkok

\subsection{The Scope, Content}

Doing this research A study of the administration according to good governance of the Office Sheikhul Islam. Bangkok The rules and procedures of governance and social good is the 2542 Corporate Governance (Good Governance), which consists of six main respects the rule of law is the moral principle of transparency. The principle involved Main responsibilities And principal value

\subsection{The scope and population samples}

Population, including people aged 18 years or more areas of Bangkok Thonburi sample of 4093 people. The stratified random sampling method (Sturatified Sampling) and scale samples using a sizing samples of Kerjcie and Morgan had a sample of 360 people.

\subsection{Scope the Place}

The preparation of this research The researchers conducted the study to determine areas in Thon Buri. Bangkok

\subsection{Benefits of Doing Research.}

1. Know the administration applying good governance of the administration bureau Sheikhul Islam. Bangkok

2. The research is the application of management principles within the organization. Of good governance The administration according to good governance of the administration according to good governance of the Office Sheikhul Islam. Bangkok 


\section{Research Result}

\subsection{Personal Status Of respondents}

The research found that Most of the respondents were male, 136 were female and 52.31 per cent of 124 people, representing 47.69 per cent between 31-40 years, 81 per cent aged 21-30 years, followed by 31.15. 46 people, representing 17.69 per cent with primary education level, number 125, representing a 48.08 percent lower levels of education. m $3 \mathrm{~m} .6$ / vocational certificate number, 97 percent. 37.31 There are farmers of 129 people representing 49.62 minor has employed 51 people as of 19.61 and earning less than 10,000 baht of 196 people representing 75.38 minor income 10001 -. 20,000 baht for 38 people, representing 14.62.

\subsection{Public Comment on the Administration by the Good Governance of the Administration Bureau Sheikhul Islam. Bangkok}

The research found that Public opinion towards administration according to good governance of the administration bureau Sheikhul Islam. Bangkok Overall, the high level (=3.67), considering that each side. In all aspects The conclusion is the following:

The rule of law The research found that The level of administration according to good governance of the Tambon Administrative Mae Kon Muang District, Chiang Rai Province. The rule of law, overall opinion on the level (= 3.55) when considering the details of each find that people have opinions on the administration applying good governance of the Tambon Administrative Mae Kon district. Chiang Rai The rule of law in the very terms of the first administrators treat people with equality, non-discrimination $(=3.76)$, followed by the performance of the Executive Bureau Sheikhul Islam is a legitimate $(=3.58)$. and closed to the public a chance to comment on the regulations $(=3.55)$, respectively.

The results showed that the moral principles on the administration of the principles of good governance Administration Bureau Sheikhul Islam. Bangkok The main virtue overall opinion on the level $(=3.71)$ when considering the details of each find that people have opinions on the administration applying good governance of the administration bureau Sheikhul Islam. Bangkok The main virtue is to a large extent all. Considering each of the first personnel to behave as a good example in society $(=3.86)$, followed by personnel Good gentle and services available (=3.75) and personnel administration based on the accurate and fair $(=3.69)$, respectively.

The principle of transparency The research found that The level of administration according to good governance of the administration bureau Sheikhul Islam. Bangkok The main transparent overall opinion. In a large pan (=3.70) when considering the details of each find. The opinions of public administration according to good governance. In all aspects Considering each of the first order is the information disseminated to the public is accurate with reality $(=3.82)$, followed by the announcement to staff about their rights and obligations in the field of religion (=3.71. ) and the work of the Bureau working Sheikhul Islam openly and honestly ready to be reviewed $(=3.69)$, respectively.

The principle involved The research found that The level of administration according to good governance of the administration bureau Sheikhul Islam. Bangkok The principle involved Overall opinion at a high level (= 3.64) when considering the details of each find. People have opinions on the administration applying good governance of the administration bureau Sheikhul Islam. Bangkok The principles involved in high level terms. Considering each of the first order is to allow people to participate in decisions that affect the public $(=3.89)$, the Bureau Sheikhul Islam allows the Muslims to offer comments on the issue. (= 3.67) and the Bureau Sheikhul Islam presents a community forum to listen to the problems and needs of the people $(=3.58)$, respectively.

The main responsibility The research found that The level of administration according to good governance of the administration bureau Sheikhul Islam. Bangkok The main overall responsibility Opinions on the level (= 3.63) when considering the details of each find. People have opinions on the administration applying good governance of the administration bureau Sheikhul Islam. Bangkok The main responsibility in all levels. 
Considering each of the first order is provided in a responsible manner (=3.87), followed by a vision. Mission and goals clearly $(=3.64)$ and the introduction of project activities or plans to carry out the stated objective $(=$ 3.58), respectively.

The main value The research found that The opinions of management on the corporate governance of the administration bureau Sheikhul Islam. Bangkok The main value overall. Opinions on the level $(=3.81)$ when considering the details of each of the public opinion on the administration by the good governance of the Office

Sheikhul Islam. The main responsibility in all levels. When considering the sequence is determined by selecting the appropriate staff and expertise to perform their duties $(=3.96)$.

\section{References}

[1] William, Holloway V. (1951). State and Local Government in The Unistates. New York: McGraw Hill.

[2] William A. Robson. (1953.) Local Govemment. Encyclopaedia of Social Science. Vol.x. New York :The Macmillan Co..)

[3] Daniel. Wit. (1967).A Comparative Sursey of Local Government and Administration. Bangkok :

[4] Kurusapha Kanjanacnaraks (1992), Curriculum Deverlopment, 2nd edition Genesis: Printing Silpakorn University[2]

[5] KriengsakChareonwongsak (2000), South wise Educators, Edition 4: A blockade net Dhaka printing.[3]

[6] Religious Affairs (1992), Registration mosque in Thailand, The degree Snoopy Waithayopathum,Bangkok[4]

[7] Sheikh Sharif Hadi (2009), Foundation Imam al-Hadi (as), Grade 5 textbook Islam Bangkok.[5] Sheikh Sharif Hadi (2009),

[8] Foundation Imam al-Hadi (as), textbook Islam grade 6 Bangkok.[6] Seiji Tanaka (1995), Development of the historical Muslim Community School. Bangkok: (Mimeographdocument), Institute of Asia-Pacific Studies, Srinakharinwirot University. 